Policy Research Working Paper 4381

The Growing Role of the Euro in Emerging Market Finance

\author{
Paul R. Masson
}

The World Bank

Development Prospects Group

International Finance Team

November 2007 
Policy Research Working Paper 0-

\begin{abstract}
More than eight years after the introduction of the euro, impacts on developing countries have been relatively modest. Overall, the euro has become much more important in debt issuance than in official foreign exchange reserve holdings. The former has benefited from the creation of a large set of investors for which the euro is the home currency, while demand for euro reserves
\end{abstract}

has been held back by the dominance of the dollar as a vehicle and intervention currency, and the greater liquidity of the market for US treasury securities. Fears of further dollar decline may fuel some shifts out of dollars into euros, however, with the potential for a period of financial instability.

This paper - a product of the International Finance Team, Development Prospects Group—is part of a larger effort in the department to analyze key international financial developments affecting the external financing conditions facing developing countries. Policy Research Working Papers are also posted on the Web at http://econ.worldbank.org. The author may be contacted through, mgamboa@worldbank.org.

The Policy Research Working Paper Series disseminates the findings of work in progress to encourage the exchange of ideas about development issues. An objective of the series is to get the findings out quickly, even if the presentations are less than fully polished. The papers carry the names of the authors and should be cited accordingly. The findings, interpretations, and conclusions expressed in this paper are entirely those of the authors. They do not necessarily represent the views of the International Bank for Reconstruction and Development/World Bank and its affiliated organizations, or those of the Executive Directors of the World Bank or the governments they represent. 


\title{
The Growing Role of the Euro in Emerging Market Finance
}

\author{
by Paul R. Masson* \\ Rotman School of Management \\ University of Toronto \\ Toronto, ON M5S 3E6 \\ CANADA \\ tel 416-946-0434, fax 416-978-5433 \\ Email: paul.masson@rotman.utoronto.ca
}

\footnotetext{
*I am grateful to Benjamin Cohen, Mansoor Dailami and Gabriele Galati for comments and discussion. An earlier version of this paper was prepared as a background study to the World Bank's 2006 Global Development Finance report. The opinions expressed are those of the author and do not necessarily represent those of the World Bank Group or its Executive Directors.
} 


\section{Introduction}

The creation of the euro more than eight years ago (on January $1^{\text {st }}, 1999$ ) was a major event in the history of the international monetary system. It has transformed the monetary landscape by eliminating a dozen European currencies and creating a large market for securities denominated in euros by investors and financial institutions for which the euro is their home currency. Correspondingly, the issuance of euro securities has increased enormously relative to the legacy currencies it replaced, not only by issuers within the euro area but also by others outside it. Other uses of international currencies, namely in trade invoicing and in foreign exchange reserves have expanded less fast. The European Central Bank issues annual reviews of the international role of the euro, and this paper will draw heavily on those reports. However, the focus of this paper will be both narrower and broader than the ECB reports: it will focus on the effect that the introduction of the euro has had on developing countries, and how that impact may evolve in the future.

It is fair to say after eight years that the effect of the introduction of the euro on developing country finances and exchange rate regimes has so far been relatively modest. How the introduction of the euro would transform the monetary system was widely debated during the late 1990s. Some suggested greater volatility of the dollar/euro rate than the dollar/DM or dollar/FFranc rates, for instance, because the euro economy was more closed (Bénassy-Quéré et al., 1997), others to the dangers that a bi-polar world might be more unstable and require more policy coordination than one with the "hegemonic stability" provided by the dollar (Bergsten, 1997). These sources of volatility could have unfavourable effects on developing countries. We examine evidence relevant to these two hypotheses below, but find no support for them.

Honohan and Lane (2001), on the other hand, expected that the euro would provide an attractive anchor currency for African countries wanting to peg, and might be a spur to the creation of common euro pegs, favouring African monetary integration. However, aside from the changeover by the CFA franc zone to a euro peg from a dollar peg, this had not been borne out by events. In sum, changes to the functioning of the international monetary system, and to the monetary environment facing developing countries, have, so far, been relatively small.

As described below, bond issuance in euro has developed much more rapidly than reserve currency use, for reasons we will explore. Even for bond issuance, so far the large expansion of euro denominated paper has come mainly from the advanced countries, and developing countries' issuance (except by those countries which are new or potential European Union members) has been small. 
However, the hegemony of the dollar as a reserve currency is being questioned because of fears that the dollar may have to depreciate substantially to restore sustainability to the US balance of payments - given a current account deficit equal to 6 percent of US GDP and net foreign liabilities (at market value) in excess of 20 percent of GDP. Already, the dollar has depreciated by over 40 percent against the euro relative to its peak. Thus, the role of the euro in the reserves of developing countries may expand in the future. The paper discusses three main models that purport to explain the demand for, and the currency composition of, reserves. Each of them has its limitations. Focusing instead on a model of optimal diversification, the paper applies a simple mean-variance model to assess the attractiveness of the euro as a reserve currency on the basis of realized returns on holdings of dollar, yen, pound sterling, and euro reserves, and compares calculated values to actual holdings. Published data on reserve composition need to be adjusted to account for incomplete reporting and reallocated accordingly. If one does so, actual reserves of developing countries are 60 percent in dollars and 30 percent in euros. While the euro's share is roughly equal to that implied by the meanvariance portfolio, the dollar's share actual share is much higher.

\section{The Present Role of the Euro in International Finance}

Since its introduction on January 1, 1999, the euro has assumed an important international role, but to varying extents depending on the dimensions one considers. Money can serve a number of international functions: as the currency in which exports and imports or external assets are denominated, as a vehicle currency for foreign exchange transactions, and as a component of official foreign exchange reserves, among others. In its 2005 review of the international role of the euro (ECB 2005), the European Central Bank highlighted the fact that bond issuance in euros far exceeds that in the legacy currencies (i.e., the national moneys of euro-area countries that were replaced by the euro). The explanation for this change lies in the effect the introduction of the euro has had in creating a single market for debt instruments in euro across a dozen countries. This is a notable change relative to the segmented markets that existed before, since a French investor purchasing bonds denominated in deutsche marks, for instance, took on exchange risk, which was also true for a German investor buying franc-denominated bonds. The elimination of intra-euro-area exchange risk has created a market for eurodenominated securities that rivals in size the US market for dollar securities. As a result, a potential issuer of bonds faces comparable terms, whether it issues in dollars or euros: underwriting fees are comparable (or may in fact be lower for euro issues ${ }^{1}$ ), and so is market liquidity for comparably sized issues. Issuance in euro increased rapidly; already in 1999, the euro was approaching the importance of the dollar. According to Bloomberg

\footnotetext{
${ }^{1}$ See "Deutsche Bank Ousts Citigroup: Demand for euro-denominated issues puts sales on a record pace for 2005," Bloomberg Markets, November 2005
} 
figures, in 2003 international issuance in euro surpassed that in dollars, and by 2005 the euro accounted for about 60 percent of international bond issuance, compared to 30 percent for the dollar.

However, the issuance of euro has been primarily by private sector entities in the advanced countries rather than developing country sovereign or non-sovereign issuers. And developing country issues are concentrated among European countries, especially those that are recent or prospective EU members. Table 1 gives a breakdown of amounts issued in euros by developing countries in 2003-05.

While the amount issued by Eastern Europe borrowers is significant, the issuance by countries in other regions is very modest. The exact definition of international bonds also makes a difference for the ranking of the two currencies, and the ECB takes a more conservative definition, in effect treating the euro area as a single country, so that international euro issues from countries within the euro area are excluded. This definition suggests about equal shares for the dollar and the euro by 2003 (see Table 2). Whatever their relative importance, it remains that the euro very quickly rivalled the dollar in bond issuance. But if we compare the issuance by developing countries in Table 1 with Table 2, we see that euro issuance by developing countries outside Eastern Europe over the $23 / 4$ years from January 2003-September 2005 (the equivalent of $\$ 25$ billion, or roughly $\$ 10 \mathrm{bn}$. annually) is only one-twenty-fifth of the total net issuance of eurodenominated bonds (about $\$ 250$ bn. annually over 2003-2005).

The relative importance of the two currencies has since changed dramatically, however, and there was a remarkable expansion in issuance of dollar securities in 2005Q3-2006Q2, far exceeding the issuance of euro-denominated debt, which stayed roughly constant relative to levels seen in 2003Q3-2005Q2. This expansion in dollar denominated debt, linked to leveraged buyouts in developed countries, has continued more recently. Time will tell if this trend is a durable one.

In other dimensions, the international role of the euro has developed less rapidly (Galati and Tsatsaronis, 2003). In foreign exchange markets, the euro's role is roughly the same as the deutsche mark's in the past. The dollar is a much more important vehicle currency, appearing as one of the currencies in a foreign exchange market trade more than twice as often as the euro. The dollar was one of the two currencies in forex transactions in 96 percent of all currency trades in 2004, and the euro only 44 percent. $^{2}$ As for exports and imports of goods and services, the euro's role in invoicing and settlement has seen notable increases in the past two years for euro area countries' trade outside the euro area, as well as for the trade of EU new member states ${ }^{3}$. Thus, the

\footnotetext{
${ }^{2}$ See ECB (2005), p. 29.

${ }^{3}$ See ECB (2005), chapter 4.
} 
euro's role at present seems to be regionally focussed. More widely, however, the dollar retains its dominant role in international trade, with many commodities, most notably energy products, being denominated in dollars.

Turning to the use of the euro as a reserve currency, the 2005 ECB report emphasized the modest increase in euros in other countries' reserves. The US dollar in 2003 remained by far the most important reserve currency by a factor of about 3 to 1 : for all countries, dollar holdings constituted 64 percent of the total, and the euro 19.7 percent-the rest consisting of Japanese yen, pound sterling, Swiss francs, and unspecified currencies. For developing countries the proportions between dollar and euro were similar, though each had a share that was slightly lower, and the share of unspecified currencies was higher.

New data, published in the IMF's 2005 Annual Report and subsequently updated, give a somewhat different picture, however. These data distinguish between additional reserve currencies and countries that did not report (something that was not done in earlier IMF calculations), and the data rely less on the use of estimation techniques to fill gaps. Data for developing countries were particularly likely to be estimated in previous IMF publications, given more frequent non-reporting of data. The new data give substantially higher shares for both the dollar and the euro, but particularly the latter. As seen in Table 3, which includes the latest IMF reserves data, the edge of the US dollar on the euro, though substantial, is considerably less. For developing countries, euro holdings at end 2006 constituted 29.6 percent of reserves, compared to 59.7 percent for the US dollar - the US dollar's advantage is roughly 2 to 1 , not 3 to 1 . Over seven years, the euro's share has risen by 10 percentage points, while the dollar's share has declined by 9 percentage points and the yen's, by 3 percentage points. The pound sterling's share has also risen, by 2 percentage points.

The stock data include both quantity changes and price changes: the euro benefited from increased valuation (due to the appreciation of the currency against the SDR), and the dollar suffered from reduced valuation. It is instructive to decompose the change in each currency's share over the seven years into two components: the change due to exchange rate changes (1999 holdings multiplied by the appreciation of the currency against the SDR, and divided by 2006 total reserves), and the remainder, which results from both a quantity increase (the deliberate acquisition of reserves in that currency) and a scale effect (the increase in the overall size of the reserves portfolio).

If we let $Q_{t}^{i}$ be the holdings of currency $i$ in period $t=0$ (1999) or 1 (2006), and $S_{t}^{i}$ be the corresponding SDR exchange rate (SDRs per unit of currency $I$ ), then currency shares are given by 


$$
\mu_{t}^{i}=\frac{Q_{t}^{i} S_{t}^{i}}{Y_{t}} \text { where } Y_{t}=\sum_{i} Q_{t}^{i} S_{t}^{i}
$$

So the change in currency shares is given by

$$
\Delta \mu_{t}^{i}=\mu_{0}^{i} \frac{\Delta S_{t}^{i}}{S_{0}^{i}}+S_{0}^{i} \Delta\left(Q_{t}^{i} / Y_{t}\right)
$$

The first term is the valuation effect, and the second term is the change in the ratio of holdings of currency $i$ to the total, when currency $i$ 's holdings are valued at 1999 exchange rates. Thus, the column marked "other" will show a decline if reserve accumulation in a particular currency, at 1999 exchange rates, does not keep pace with total reserves.

Table 4 presents the raw numbers for reserves as well as the proportion of reported reserves that were broken down into identified reserve currencies (the rest were not allocated across currencies). Several things are worth noting. First, the proportion of allocated reserves is much higher for industrial countries, while the share of the dollar is much higher for these countries than for developing countries. Second, the proportion of allocated developing country reserves has fallen even lower in recent years, and is currently only a bit over half. Third, developing country reserves have grown enormously since 1999; in that year, allocated reserves were well below industrial country levels (though their total reserves were higher, SDR 760 billion versus SDR 525 billion). In 2006, in contrast, allocated reserves of developing countries were 40 percent higher, and their total reserves more than twice those of industrial countries.

Turning to the changes in shares, 1999 to 2006, a substantial fraction of the decline in the dollar's share for industrial countries (2.6 percentage points) is due to valuation effects - the depreciation of the dollar against the SDR - and this component more than explains the fall in the dollar's share. The 3 percentage point increase in the euro's share is only partly (1.3 percentage points) due to valuation. For developing countries, because the 1999 stock was relatively smaller, the valuation effects account for a smaller drop in the dollar's share, and the total decline ( 8.6 percentage points) is mainly due to quantity changes and scale effects (the latter reflect the general rise in the levels of reserves, which reduces the share of an unchanged reserve stock). Similarly, the rise in the euro's share in developing countries' allocated reserves, 9.7 percentage points, is mostly due to quantity changes and scale effects (all but 1 percentage point).

While the new IMF data are an improvement, they require a further key adjustment to get a better estimate of the currency composition of global reserves. The published IMF figures for overall reserve holdings by currency, which give a share of only 25.8 percent for the euro in 2006, are of dubious value given the markedly different extent of reporting 
of currency composition by industrial and developing countries. Instead of just adding up holdings of those countries that report the currency breakdown, the IMF should make an estimate that treats developing countries differently, since the latter have a greater proportion of non-reporters, and they also tend to hold a greater proportion of euros than do developed countries. If the other developing-country reserves are allocated the same way as those which are reported in Table 4 (and similarly for the small amount of nonallocated industrial-country reserves), the global reserve stock of SDR 3,342 billion in 2006 would correspond to dollar and euro shares of 63.0 and 27.1 percent, not 64.7 and 25.8 percent, respectively, as reported ${ }^{4}$.

\section{Projecting the Demand for Reserves and External Debt, and Explaining Their Currency Composition}

\section{a) The Level of Reserves and External Debt}

Projecting the use of the euro requires first an analytical framework for understanding the reason for the accumulation of reserves. In this regard, a puzzle has been the continued accumulation of reserves by emerging-market developing countries despite their official move to greater exchange rate flexibility. In recent years, East Asia in particular has continued to accumulate large reserves, and, as described in section 2, China is one of the top two holders of foreign exchange reserves (with Japan). Other East Asian economies, such as Hong Kong SAR, Malaysia, and Singapore also hold large reserves, as well as Korea and Taiwan POC.

There are three principal contenders for explaining the large accumulation of reserves in Asia: 1) buffering exports and imports, 2) a "new Bretton Woods system" with Asian countries deliberately undervaluing their currencies and accumulating US dollar claims, and 3) a precautionary demand for reserves to counter "sudden stops" of external financing.

The traditional literature (Frenkel and Jovanovic, 1981) has stressed the buffer stock role of reserves, to meet liquidity needs in the face of stochastic export and import flows. However, as pointed out by Aizenman and Marion (2002), this theory does not explain the rapid growth in foreign exchange reserves in Asia since 1998, especially since that period has been characterized by a benign international environment accompanied by greater exchange rate flexibility than previously, if not for China or Hong Kong, at least for the other emerging market countries of the region.

An alternative theory, characterized as "mercantilism" or "the New Bretton Woods System," and due to Dooley et. al. (2003), associates Asian countries' reserve accumulation with a deliberate attempt to maintain undervalued currencies so as to export

\footnotetext{
${ }^{4}$ The (corrected) figures for 1999 would be 70.4 and 18.3 percent, respectively.
} 
to the United States and achieve domestic "export-led" growth. They liken this system, in which their trade surpluses with the United States are then recycled to the US in the form of accumulation of US treasury securities (held as reserves by the Asian countries) to the relation between the center country (the US) and the periphery (the rest of the world) during the period of fixed but adjustable parities in force between 1945 and 1973. The rest of the world wanted to accumulate reserves in the form of claims on the reserve currency country, the United States, and this permitted the latter to run a balance of payments deficit since it financed world reserve growth.

However, the parallel with the earlier period is imperfect, as in that period the United States typically ran current account surpluses, not deficits; it was the US short-term capital account that was in deficit. The US in effect played the role of financial intermediary, providing international liquidity in the form of short-term, relatively riskless and liquid assets that served in part as official foreign exchange reserves in the rest of the world, the US for its part accumulating longer term claims on the rest of the world $^{5}$. In the current situation, rather than being just an intermediary, the US is using external financing to consume more than it produces, running a current account deficit which exceeded $\$ 800$ billion in 2006. Moreover, the export-led strategy of East Asian countries is not new, while the vast accumulation of reserves by Asian emerging market countries is a phenomenon that is comparatively recent, that is, since 1998.

A third model, due to Aizenman and Marion (2002, 2004), links reserve holdings to the precautionary accumulation of reserves not to cushion variability of current account flows, but rather to guard against capital account crises - the "sudden stops" to which they were subject during the devastating financial crises of 1997-98 ${ }^{6}$. Thus, they put forward a model in which both external borrowing and holding of reserves are the result of an optimizing decision by countries, in the face of volatility in the balance of payments. If default is ruled out, then only the net position (reserves minus external debt) is relevant; but in the face of possible default, the demands for each of them individually are identified. Foreign exchange reserves (those at least that are not attachable by foreign creditors) would allow the country to face the sudden stop of further capital inflows without a severe contraction in imports and resulting output crash-which is what they suffered in 1997-98.

Such a model has the advantage of giving an explanation of the reserves behaviour of East Asian countries during the last few years, but the link between reserves and the

\footnotetext{
${ }^{5}$ As a result of the maturity mismatch, in part, the US earns more on its foreign assets than it pays on its foreign liabilities. See Gourinchas and Rey (2005).

${ }^{6}$ This is also the explanation given by Federal Reserve Board Chairman Bernanke for the large current account deficits of the United States. See "The Global Saving Glut and the US Current Account Deficit," remarks at the Homer Jones Lecture, St. Louis, Missouri, April 14, 2005.
} 
possibility of default seems too simplistic. In particular, it is not so much the risk of default as the possibility of facing disadvantageous conditions when trying to borrow on international capital markets that makes holding reserves attractive. Moreover, Aizenman and Marion's model does not give a ready prediction (without considerable additional empirical work) of the level of reserves that would be adequate to meet the precautionary need. Presumably, after having built up an adequate stock, further accumulation (except that which would allow for trend growth) would be unnecessary. Finally, the story does not seem to fit very well the case of the largest emerging market holder of reserves, China, which has little external debt and which did not suffer a crisis in 1997-98. Despite this, it has continued to accumulate reserves which new exceed $\$ 1$ trillion.

Prasad and Wei (2005) examine the Chinese capital account and reserves in some detail. They tend to reject the "mercantilist" explanation of Chinese reserve accumulation. Instead, they link the recent accumulation with the occurrence of "hot money" inflows that have evaded capital controls and that may be speculating on an appreciation of the renminbi. However, those inflows are covered many times over by the stock of reserves, so that their explanation is also incomplete.

Genberg et al. (2005) also throw doubt on the hypothesis that Asian currencies are being deliberately undervalued, and link reserve accumulation to portfolio inflows. They find only weak evidence that Asian dollar reserve accumulation has any important effect on keeping US interest rates low.

\section{b) Currency Composition}

The theoretical literature on the currency denomination of debt and reserves focuses on the advantages of cushioning the stochastic fluctuations of exports and imports by hedging their currency exposure. However, this focus is not completely satisfactory. As argued above, liquidity is also important, and it is likely to be more important for holding reserves than debt issuance. Liquidity of the secondary market for debt will be important for purchasers of that debt, but not necessarily for the issuer, and it is the latter that determines the choice of currency (albeit in response to the cost of issuing in the different currencies). In contrast, the official holders of reserves potentially need to be able to access them quickly and in difficult market conditions, where the ability to turn reserve assets into cash for intervention purposes at the prevailing market price will be of the first importance $^{7}$. Thus, the fact that the liquidity of markets for euro-denominated government debt is limited by the existence of a number of different national issuers, when compared to the US treasury, helps to explain why the role of the euro in foreign

\footnotetext{
${ }^{7}$ In this regard, reserves need to be distinguished from other assets held by the official sector which are held primarily for investment purposes, as opposed to foreign exchange market intervention. See below.
} 
exchange reserves has lagged its development as a currency for debt issuance, relative to the dollar.

Theoretical models that consider optimal portfolio composition in terms of a meanvariance, or capital asset pricing, models, typically equate debt issuance with negative reserve holding. For instance, Claessens (1992) treats the two as being part of the same decision, and he analyses the optimal currency composition of the net debt position (external debt minus foreign exchange reserves). Thus, the optimal portfolio takes into account the variations of a country's export and import prices, and how they are related to the variance of reserve currencies. The optimal portfolio consists of a speculative portfolio (whose weight depends on the degree of risk aversion of the investor), a minimum variance portfolio, and a hedging portfolio that depends on covariances of the assets with commodity prices. His analysis, applied to Mexico and Brazil, gives very volatile portfolio proportions due to changing covariances. This prediction does not square well with the well-known stability of countries' reserve assets. Though central banks could presumably use currency swaps and dynamic hedging techniques to achieve that optimal portfolio, they do not typically seem to do so.

Thus, diversification models seem more applicable to the denomination of debts rather than reserves, and this is indeed the primary focus of Claessens' article. He calculates the risk-minimizing hedging portfolio for Brazil and Mexico for the period 1973-89, finding that both countries should have borrowed primarily in US dollars (borrowing negligible quantities of deutsche mark, and holding small amounts of reserves in yen). Kool (2000) calculates the optimal bond portfolios of investors resident in the euro area, the UK, Japan and the US, using a mean-variance model and each country/region's currency as numeraire. Not surprisingly, each of the countries/regions would, according to the optimal portfolio allocation, hold a preponderance of the bonds issued in its own currency (because this would eliminate an important source of fluctuation of returns, due to the volatility of nominal exchange rates).

Another interpretation of the application of portfolio diversification models to reserve choice is to assume that the implied optimal portfolios should approximate the long-run choices of central banks, after inertia has worked itself out. Inertia could potentially be due to a variety of causes, including, perhaps, the slow development of market liquidity. Thus, the optimal portfolios, when compared to actual reserve holdings, could give an indication of long-run trends in the composition of reserves. This was the interpretation given in Masson and Turtelboom (1997), where a mean-variance model with historical returns were used to calculate optimal reserve holdings, in dollars, yen, and euros. In order to consider global reserve demand, returns were expressed in terms of the SDR, chosen as the numeraire. The study gave an optimistic assessment of the demand for euro reserves after lags had worked themselves out: the optimal portfolio suggested a 
greater potential role for the euro than for its legacy currencies (in particular the deutsche mark), and one comparable to the US dollar.

Since both Masson and Turtelboom (1997) and Kool (2000) relied on data for the deutsche mark (and other European currencies replaced by the euro), rather than for the euro itself, now that we have about 8 years of data on euro returns the exercise merits being redone. Table 5 lists the monthly returns $R$ to holding assets paying the one-month Libor rate $r$ on US dollars, euros, pound sterling, and Japanese yen, respectively, over the period January 1999-March 2007, expressed as an ex post annualized return in SDRs using the monthly change in the SDR spot exchange rate $S$, that is

$$
R=\left((1+r / 100) \cdot\left(S_{+1} / S\right)^{12}-1\right) \cdot 100
$$

Average returns from holding pounds sterling are the highest, followed by euro returns; both of these currencies appreciated against the SDR over the period. Returns to holding US dollars are somewhat lower, reflecting depreciation of the dollar over this period, while returns on yen were depressed by very low nominal interest rates. However, the US dollar benefits from the lowest variability among the currencies. There is also a strong negative covariance between dollar and euro returns.

Suppose that these four currencies (which are the components of the SDR) constitute the set of available assets for the portfolio of reserves, and that a country's imported consumption basket is composed of the goods of the US, UK, Japan and the euro area in the same proportions as they appear in the SDR basket. Assuming that all assets are risky, and that holders of reserve assets are risk averse, the mean-variance model implies that a reserves portfolio should be allocated among the four currencies in proportions embodied in the vector $x$ given by

$$
x=\Omega^{-1} \rho / 1^{\prime} \Omega^{-1} \rho
$$

where $\rho$ is a vector of expected real returns, $\Omega$ is the covariance matrix of returns, and $l$ is a vector of ones. By construction the proportions $x$ sum to unity, i.e.

$$
1^{\prime} x=1
$$

This model can be used as a benchmark for a stylized developing country's portfolio- one whose consumption basket corresponds to the SDR basket ${ }^{8}$. Using the realized returns, expressed in terms of the SDR, minus the rate of inflation on the SDR (the consumer price indexes for the US, UK, Japan and the euro area, weighted together), we can calculate such a country's optimal reserves portfolio. Optimal currency shares are

\footnotetext{
${ }^{8}$ The model is more problematic when applied to industrial countries, since they include the countries that issue the reserve currencies. The United States, currently at the center of the international monetary system, does little intervention and hence holds few reserves. European central banks hold substantial reserves, mainly in dollars, since (aside from the euro) the dollar is the only significant reserve currency.
} 
39 percent for the dollar, 28 percent for the euro, 19 percent for pound sterling, and 14 percent for the yen. Interestingly, despite higher ex post returns to holding euros than dollars, the optimal portfolio calculated using this model gives a much lower proportion for the euro than for the dollar. The proportion for the euro is significantly below that calculated for the deutsche mark in Masson and Turtelboom (1997), despite a similar methodology. The reason is that in that study, the mean returns (calculated over 1981-95) on both deutsche mark and yen were considerably higher than dollar returns, and they were less variable as well. The calculated optimal portfolio in Masson and Turtelboom implied roughly equal shares for the dollar and deutsche mark/euro (about 38 percent), and a lesser share for the yen (about 23 percent) ${ }^{9}$.

Table 5 compares the optimal shares to the SDR weights (using July 2007 exchange rates to calculate the latter) as well as to actual reserve proportions for developing countries. In all three weightings, the euro is second only to the dollar. While the euro's share in the optimal portfolio is below its weight in the SDR, it is very close to its share in actual reserve holdings by developing countries. In contrast, the dollar's optimal share is close to its SDR share, but considerably below its actual share of developing country reserves. The optimal shares for the yen and pound sterling, conversely, are similar to SDR weights but well above actual ones.

Historical returns may of course not give a good indication of what returns will be on these four currencies in the future. In particular, the large US current account deficit has raised fears that the value of the US dollar may fall further in international currency markets. Such an expectation might produce a shift away from dollar reserves in favour of euros. In addition, the mean-variance exercise when applied to individual countries would use that country's consumption basket, which would no doubt differ from the SDR basket. It is likely to give widely differing portfolio weights for different countries. What is striking, however, is that in actuality the dollar seems to be a most important part of almost all countries' reserves, except those countries that peg to another currency-such as those that peg to the euro.

\section{c) Reasons for Inertia in Reserve Holdings}

It has long been recognized that reserve currency use evolves slowly, the prime example being the time it took the US dollar to overtake sterling as the world's major currency, despite the fact that the US economy had overtaken the UK's in size long before. Several reasons have been adduced for that inertia (see Cohen, 2000). Most important is that holdings of reserve currency reflect the currency's importance in other dimensions: denomination of trade, anchor currency, vehicle for trading in foreign exchange markets, store of value, etc. Since each of these uses, to a greater or lesser extent, evolves slowly,

\footnotetext{
${ }^{9}$ Only these three reserve currencies were considered.
} 
then the incentives for changing reserve currencies are likely to develop even more slowly. Hence the incumbent is likely to dominate over any challengers for a long time.

A further issue, as Cohen (2000) notes, is that choosing an alternative currency is a risky option for any individual holder, since it depends for its success on others also deciding to use that currency. In other words, there are network externalities, and such externalities may justify history dependence and multiple equilibria in the use of a medium of exchange.

Finally, switching out of the incumbent reserve currency may induce adverse exchange rate movements, so that large holders may be reluctant to do so openly. Such a consideration may be important in the current context for large official Asian holders of US dollars, who seem to be very cautious about suggesting any diversification away from dollar holdings - especially in the light of the publicity that statements from the Bank of Korea of its intention to diversify attracted a few years ago.

\section{d) Liquidity}

The introduction of the euro has had an important effect in integrating European markets for both government and private-sector bonds (for an assessment, see Pagano and von Thadden, 2004; Galati and Tsatsaronis, 2003; ECB, 2007b). Most dramatic have been the convergence of government bond yields and the creation of a European corporate bond market as a result of the elimination of intra-euro-area exchange rate risk. The ability of investors to invest across borders without taking on exchange rate risk has allowed the creation of pan-European markets for securities, increasing liquidity and permitting better diversification of risks. Securities issued by different borrowers remain imperfect substitutes, reflecting different credit risks. This is obvious in the case of commercial issuers with different ratings, but is also true of the market for government bonds, where (small) differentials associated with different credit risks remain. ECB (2007b) notes that corporate bond yields show little evidence of country effects, and cross-border holdings by financial institutions of long-term debt have grown strongly, approaching 60 percent of the total in 2005. Both of these phenomena are evidence of a high degree of integration of euro-area bond markets.

The creation of a euro-area wide market for debt securities by a particular issuer has fundamentally changed the perspective of non-euro area borrowers. While the effect on liquidity and transactions costs has been dramatic, implications have been much more important for the incentives to issue debt than for the holding of euro reserves. While the liquidity of the debt of any given issuer has increased, it has not created a market for government securities with the liquidity of the market for US treasuries. Debt issues by Germany, France, and Italy remain imperfect substitutes, so that the price impact of selling reserve holdings in euros is greater than it would be for selling dollar reserves held 
in U.S. treasury securities. As Cooper (1997) argued before the introduction of the euro, the attractiveness of the US dollar as a reserve currency is in large part derived from the existence of a deep and liquid market in U.S. treasury securities, and in particular in treasury bills: "Amounts measured in billions of dollars can be bought or sold readily, 24 hours a day, anonymously, without influencing the price of the outstanding bills. There is nothing comparable to this market on the European continent, or in Japan, and there is not likely to be for decades to come." 10 The short-term government paper market has suffered from the preference of the German government for longer-term securities; France and Italy have large markets for government debt, but nothing comparable to that in the United States. No single euro-zone country establishes benchmarks for bonds across the maturity spectrum. In addition, long-term bond markets have been more liquid in the United States: at end-1997, bid-asked spreads for on-the-run 10 year government bonds in secondary markets were only 3 basis points in the United States, compared to 4 , 6, and 10 basis points in Germany, Italy and France, respectively. ${ }^{11}$ More recent data suggest that the bid-asked spreads on bunds are now more similar to those on US treasuries ${ }^{12}$, but volumes remain lower. The relative scarcity of short-term German government paper remains a problem, as do national differences in the treatment of collateral for the repo market (Galati and Tsatsaronis, 2003).

\section{Prospects for Further Development of the Use of the Euro}

While the existence of a large pool of euro investors will continue to make debt issuance in euros attractive for developing countries, inertia in reserve currency use and limits on the liquidity of short-term euro instruments will continue to retard the development of the euro as an international currency for use in exchange market intervention and reserve holdings. The fragmented nature of the European markets for government bonds remains, despite the creation of the euro. It is possible to imagine innovative solutions that would increase the liquidity of European markets, for instance the creation of a single issuer of government short term paper, as proposed by Alexandre Lamfalussy. ${ }^{13}$ However, the prospect for such an institution, which presumably would buy up a significant amount of the euro area governments' issues, seems distant. As Galati and Tsatsaronis (2003) note, creating such an agency would imply shared responsibility for servicing government debt - contrary to the spirit of the Maastricht Treaty.

In considering future reserve currency use, it is important to distinguish the holding of reserves for intervention purposes from those that constitute an investment portfolio,

\footnotetext{
${ }^{10}$ Cooper (1997), pp. 12-13.

11 "The Size and Liquidity of Government Bond Markets," BIS Quarterly Review, November 2000, p. 54.

${ }^{12}$ I am grateful to Gabriele Galati for this information.

${ }^{13}$ Speech to the symposium "Capital Markets and Financial Integration in Europe," held at the European Central Bank on April 29-30, 2002.
} 
where rates of return rather than liquidity are most important. In particular, the size of reserves held by a number of Asian countries exceeds the amount that would be needed on a day-to-day or month-to-month basis to smooth shortfalls of receipts of foreign currencies and to provide liquidity to the foreign exchange market. China and Japan each have reserves of about one trillion dollars, dwarfing those of any of the other industrial countries, while several other emerging Asian economies have reserves in excess of $\$ 100$ billion.

If reserves are held as part of an investment portfolio, then the mean-variance considerations that were used to calculate optimal portfolio shares (Table 5) would be expected to come into play. As noted, the optimal shares would suggest a decline in dollar holdings. There are several reasons why official reserves may have such an investment purpose. For instance, countries may want to hold external assets in order to diversify away country-specific risks. This is especially true of small economies like Singapore or Hong Kong, and indeed diversification may involve acquiring a wider range of assets, including equities. In Korea's case, reserve accumulation has also been linked to the eventual financial needs for reconstruction of North Korea, in the anticipation of the reunification of North and South Korea.

\section{a.) Exchange Rate Pegs}

A country with a currency board and an exchange rate peg to a single other currency needs to back its monetary base with assets denominated in that anchor currency. Hence there is demand for euro reserves on the part of some of the new members of the European Union, like Estonia. In Argentina, when the Convertibility Law, guaranteeing a fixed exchange rate between the peso and the US dollar, was in place, reserves needed to be held in US dollars.

The situation is somewhat different for countries with exchange rate pegs that do not mandate that the monetary base must be backed one-for-one by foreign exchange reserves, or for cases like Hong Kong where reserves are held in excess of the backing needed for the monetary base. For instance, China's liquid reserves held for intervention purposes could be held in US dollars, but China's reserves for investment purposes could be in a range of currencies. Total reserves exceed the amount needed for intervention purposes by a substantial amount, even were the renminbi's peg to the US dollar continue. Even if initially acquired in the form of US dollar reserves, those reserves could be swapped into another currency. Euro assets could constitute an attractive alternative to US dollar assets in this regard.

\section{b) Moves to Greater Exchange Rate Flexibility}

The demand for foreign exchange reserves for intervention purposes itself can be expected to decline, given a trend toward greater exchange rate flexibility among 
emerging market economies. Over the past decade, Mexico, Russia, Brazil, South Africa, and Argentina, among others, have abandoned fixed or crawling pegs and moved to flexible exchange rates. Asian Newly Industrializing Economies have also generally introduced more flexibility into their de facto pegs or managed floats. China's need to accumulate dollar reserves would fall sharply if it allowed the renminbi to float upward in the face of current and capital account surpluses. China's announced policy of moving to greater flexibility would reduce the need for intervention, by limiting it to the smoothing of fluctuations (though it might still want to accumulate reserves for other purposes). While some concern to limit exchange rate volatility and to guard against capital account crises would explain continuing substantial reserves, greater flexibility would likely dampen further reserve accumulation.

While dollar peggers are becoming fewer, the process of euro-area enlargement is producing more peggers to the euro. The 12 new EU member countries admitted since June 1, 2004, and prospective new EU members are expected eventually to join the euro area. Doing so requires membership for at least two years in the exchange rate mechanism of the European Monetary System (ERM II), with a central parity fixed in terms of the euro and maintenance of the rate within intervention bands. These countries, though relatively small in economic size, hold much of their reserves in euros, and that proportion is likely to increase (ECB 2005, pp. 54-55), fuelling demand for euro reserves.

\section{c) Implications of a Bi- or Multi-polar Currency World for Developing Countries}

The effect of the introduction of the euro on developing countries has so far been muted. The euro has become important in some dimensions but not all-as discussed above. Chinn and Frankel (2005, p. 20) concluded when assessing the reserve currency role of the euro that "under any plausible scenario, the dollar will remain far ahead of the euro and other potential challengers for many years." While more recent trends (see Tables 34) suggest that the euro continues to make inroads, it is true that the advent of a bi-polar world, has not (yet) occurred. As for exchange rate volatility, though the euro has fluctuated about 15 percent more than the deutsche mark over the previous 7 year period (comparing the standard deviation of changes in SDR exchange rates - see Table 6), this is not the qualitative change in the international monetary system that some had feared (Bénassy-Quéré et al, 1997). Despite some swings in currency values, monetary policy coordination between Europe and the United States has not been on the agenda. Thus the supposed decline in hegemonic stability associated with the dollar as the sole reserve currency have not generated a demand for policy coordination. Instead, both areas have oriented their monetary policies to domestic inflation and activity, and low inflation has led to historically low interest rates on both sides of the Atlantic. The need for policy coordination is greater with respect to some Asian countries, notably China, accused by the United States of keeping their currency's value artificially low. 
Nevertheless, the implications of the launch of the euro for developing countries are already important and could become more far-reaching in the future. The availability of the euro as an alternative to US dollar borrowing allows better hedging of risks. Given the importance of trade with the euro area, hedging of terms of trade fluctuations would optimally give a substantial weight to the euro in external debt. At present, outside the countries geographically close to the euro area, sovereign debt issuance in euros has been small (ECB 2005, 2007a). Such a situation can be expected to change over time. As well as hedging trade fluctuations, a mix of debt in euros as well as dollars would decrease the effect of changes in U.S. monetary policy on developing countries' debt service obligations, and on their ability to repay, which is substantial at present (Dailami et al., 2005). While holding euro debt would correspondingly subject developing countries to unexpected movements in the ECB's monetary stance, since dollar and euro interest rate movements are not perfectly correlated, there is something to be gained from diversification.

Increased debt issuance in euro may also lead to increased holdings of euros in reserves, while global imbalances may lead to expectations of lower dollar returns than in the past. While noting that reserve currency use is subject to inertia, Eichengreen and Mathieson's (2000) empirical results using pre-euro data show that the currency denomination of debt is a strong predictor of reserve currency use. The size of the US current account deficit and the anticipated need for further real effective depreciation of the dollar to help correct that deficit may in the future weigh heavily on the dollar. While the range of estimates of dollar depreciation is wide, an extended period of dollar depreciation might produce widespread shifts out of nominal dollar-denominated assets, to the benefit of the euro. Chinn and Frankel (2005) consider various scenarios for future reserve currency use, and those with dollar depreciation as well as UK membership in the euro zone see the euro overtaking the dollar by 2020 .

Should it come about, a bi- or multi-polar world may produce occasional large movements in exchange rates that have serious consequences for developing countries. Policy coordination between the euro area and the United States could then be crucial to prevent disorderly markets and financial instabilities. Policy coordination may not be necessary in normal times between the dollar area and the euro area, when floating exchange rates, accompanying monetary policies that are oriented primarily to achieving domestic targets for inflation and economic activity, do their job in facilitating adjustment to different shocks hitting the two regions. More problematic are times when there are reasons to be concerned about the sustainability of existing exchange rates. In those times, policy coordination may be desirable to guide currency values or limit the rapidity of exchange rate movements and prevent disorderly markets. This was the situation in the mid-1980s, when the US dollar was widely perceived to be overvalued, and the Plaza 
Agreement of September 1985 helped bring about a "soft landing" of the dollar. The current situation resembles in some regards the earlier period. Developing countries would suffer from such instability, and hence have a shared interest in seeing cooperation in international monetary relations between the euro and dollar zones. This may be especially true now, when countries' reserves and international borrowings are predominantly in dollars. 


\section{References}

Aizenman, Joshua (2005), "International Reserves," in The New Palgrave Dictionary of Economics, ed. by S.N. Durlauf and L.E. Blume, forthcoming, Palgrave Macmillan.

Aizenman, Joshua, and Nancy Marion (2002), “The High Demand for International Reserves in the Far East: What's Going On?" Journal of the Japanese and International Economies, vol. 17, pp. 370-400.

Aizenman, Joshua, and Nancy Marion (2004), "International Reserves Holdings with Sovereign Risk and Costly Tax Collection," Economic Journal, vol. 114, pp. 56991.

Bénassy-Quéré, Agnès, Benoît Mojon, and Jean Pisani-Ferry (1997), "The Euro and Exchange Rate Stability," in EMU and the International Monetary System, ed. by P. Masson, T. Krueger, and B. Turtelboom, Washington, DC: International Monetary Fund, pp. 157-193.

Bergsten, C. Fred (1997), "The Impact of the Euro on Exchange Rates and International Monetary Cooperation," in EMU and the International Monetary System, ed. by P. Masson, T. Krueger, and B. Turtelboom, Washington, DC: International Monetary Fund, pp. 17-48.

Chinn, Menzie and Jeffrey Frankel (2005), NBER Working Paper No. 11510, Cambridge, MA.

Claessens, Stijn (1992), "The Optimal Currency Composition of External Debt: Theory and Applications to Mexico and Brazil," World Bank Economic Review, vol. 6(3), September.

Cohen, Benjamin J. (2000), "Life at the Top: International Currencies in the Twenty-First Century," Princeton Essays in International Finance, No. 221, December.

Dailami, Mansoor, Paul Masson, and Jean Jose Padou (2005), "Global Monetary Conditions versus Country-Specific Factors in the Determination of Emerging Market Debt Spreads," forthcoming in the Journal of International Money and Finance.

Dooley, Michael, David Folkerts-Landau, and Peter Garber (2003), "An Essay on the Revived Bretton Woods System,” NBER Working Paper No. 9971, Cambridge, MA. 
Eichengreen, Barry and Donald Mathieson (2000), "The Currency Composition of Foreign Exchange Reserves: Retrospect and Prospect," IMF Working Paper WP/00/131, published as chapter 10 of The Impact of EMU on Europe and the Developing Countries, ed. by C. Wyplosz, Oxford, Oxford University Press.

ECB (2005), Review of the International Role of the Euro, Frankfurt, European Central Bank, January.

ECB (2007a), Review of the International Role of the Euro, Frankfurt, European Central Bank, June.

ECB (2007b), Financial Integration in Europe, Frankfurt, European Central Bank, March.

Frenkel, Jacob and B. Jovanovic (1981), "Optimal International Reserves: A Stochastic Framework,” Economic Journal, vol. 91, pp. 507-14.

Galati, Gabriele and Kostas Tsatsaronis (2003), "The Impact of the Euro on Europe's Financial Markets," Financial Markets, Institutions and Instruments, vol. 12, no. 3 (August), pp. 165-221.

Genberg, Hans, Robert McCauley, Yung-Chul Park, and Avinash Persaud (2005), Official Reserves and Currency Management in Asia: Myth, Reality, and the Future, Geneva Reports on the World Economy, International Centre from Monetary and Banking Studies and Centre for Economic Policy Research, Geneva and London.

Gourinchas, Pierre-Olivier and Hélène Rey (2005), "From World Banker to World Venture Capitalist: US External Adjustment and the Exorbitant Privilege," NBER Working Paper No. 11563, Cambridge, MA.

Honohan, Patrick and Philip R. Lane (2001), "Will the Euro Trigger More Monetary Unions in Africa?" in The Impact of EMU on Europe and the Developing Countries, ed. by C. Wyplosz, Oxford, Oxford University Press, chapter 12.

IMF (2005), Annual Report of the Executive Board for the Financial Year Ended April 30, 2005, Washington, DC, International Monetary Fund.

Kool, Clemens (2000), "International Bond Markets and the Introduction of the Euro," Review, Federal Reserve Bank of St. Louis, September/October, pp. 41-56.

Masson, Paul and Bart Turtelboom (1997), "Characteristics of the Euro, the Demand for Reserves, and Policy Coordination under EMU," in EMU and the International Monetary System, ed. by P. Masson, T. Krueger, and B. Turtelboom, Washington, DC: International Monetary Fund, pp. 194-224. 
Pagano, Marco, and Ernst-Ludwig von Thadden (2004), "The European Bond Markets under EMU," Oxford Review of Economic Policy, vol. 20 (4), pp. 531-554.

Prasad, Eswar, and Shang-Jin Wei (2005), “The Chinese Approach to Capital Inflows: Carrots and Sticks, or Deeper Forces at Work?” IMF Working Paper WP/05/79 (April). 
Table 1. Issuance of Euro-Denominated Bonds by Developing Countries, January 2003-Sept. 2005

\begin{tabular}{lcc}
\hline & $\begin{array}{c}\text { Total Amount Issued } \\
\text { (Euro bn.) }\end{array}$ & Average Maturity (years) \\
\hline Eastern Europe & 30.33 & 10.7 \\
Middle East/Africa & 3.95 & 9.0 \\
Asia & 3.83 & 7.4 \\
South Asia & 0.11 & 5.0 \\
North America & 3.24 & 11.6 \\
Central America & 0.55 & 7.5 \\
South America & 13.54 & 21.8 \\
Total & 55.55 & 13.1 \\
\hline
\end{tabular}

Source: World Bank, Global Development Finance database.

Table 2. Net Issuance ${ }^{1 /}$ of International Debt Securities in billions of US dollars

\begin{tabular}{ccccc}
\hline & 2002Q3-2003Q2 & 2003Q3-2004Q2 & 2004Q3-2005Q2 & 2005Q3-2006Q2 \\
\hline Euro & 156.6 & 206.6 & 278.0 & 220.0 \\
US dollar & 155.2 & 285.1 & 237.2 & 486.9 \\
Japanese yen & -34.8 & 2.5 & -8.8 & 5.7 \\
\hline
\end{tabular}

Source: ECB $\left(2005,2007^{\mathrm{a}}\right)$, Table 1, and author's calculations..

$1 /$ Excluding home country issuance. 
Table 3. Composition of Foreign Exchange Reserves, end-year in percent of allocated reserves by group of countries

\begin{tabular}{|c|c|c|c|c|c|c|c|c|}
\hline & 1999 & 2000 & 2001 & 2002 & 2003 & 2004 & 2005 & 2006 \\
\hline \multicolumn{9}{|c|}{ All countries } \\
\hline $\begin{array}{l}\text { US dollar } \\
\text { pound } \\
\text { Japanese }\end{array}$ & $\begin{array}{r}71.0 \% \\
2.9 \%\end{array}$ & $\begin{array}{r}71.1 \% \\
2.8 \%\end{array}$ & $\begin{array}{r}71.5 \% \\
2.7 \%\end{array}$ & $\begin{array}{r}67.0 \% \\
2.8 \%\end{array}$ & $\begin{array}{r}65.9 \% \\
2.8 \%\end{array}$ & $\begin{array}{r}65.8 \% \\
3.4 \%\end{array}$ & $\begin{array}{r}66.7 \% \\
3.6 \%\end{array}$ & $\begin{array}{r}64.7 \% \\
4.4 \%\end{array}$ \\
\hline $\begin{array}{l}\text { Yen } \\
\text { Swiss }\end{array}$ & $6.4 \%$ & $6.1 \%$ & $5.1 \%$ & $4.4 \%$ & $3.9 \%$ & $3.9 \%$ & $3.6 \%$ & $3.2 \%$ \\
\hline franc & $0.2 \%$ & $0.3 \%$ & $0.3 \%$ & $0.4 \%$ & $0.2 \%$ & $0.2 \%$ & $0.1 \%$ & $0.2 \%$ \\
\hline euro & $17.9 \%$ & $18.3 \%$ & $19.2 \%$ & $23.8 \%$ & $25.2 \%$ & $24.9 \%$ & $24.2 \%$ & $25.8 \%$ \\
\hline other & $1.6 \%$ & $1.5 \%$ & $1.3 \%$ & $1.6 \%$ & $2.0 \%$ & $1.9 \%$ & $1.7 \%$ & $1.7 \%$ \\
\hline \multicolumn{9}{|c|}{ Industrial countries } \\
\hline US dollar & $73.5 \%$ & $72.7 \%$ & $72.7 \%$ & $68.9 \%$ & $70.5 \%$ & $71.5 \%$ & $73.6 \%$ & $71.9 \%$ \\
\hline $\begin{array}{l}\text { pound } \\
\text { Japanese }\end{array}$ & $2.2 \%$ & $2.0 \%$ & $1.9 \%$ & $2.1 \%$ & $1.5 \%$ & $1.9 \%$ & $2.1 \%$ & $2.5 \%$ \\
\hline $\begin{array}{l}\text { Yen } \\
\text { Swiss }\end{array}$ & $6.7 \%$ & $6.3 \%$ & $5.5 \%$ & $4.3 \%$ & $3.8 \%$ & $3.6 \%$ & $3.4 \%$ & $3.5 \%$ \\
\hline franc & $0.1 \%$ & $0.2 \%$ & $0.3 \%$ & $0.6 \%$ & $0.2 \%$ & $0.1 \%$ & $0.1 \%$ & $0.2 \%$ \\
\hline euro & $16.1 \%$ & $17.0 \%$ & $17.9 \%$ & $22.3 \%$ & $21.9 \%$ & $20.8 \%$ & $19.0 \%$ & $20.4 \%$ \\
\hline other & $1.5 \%$ & $1.7 \%$ & $1.6 \%$ & $1.8 \%$ & $2.0 \%$ & $2.1 \%$ & $1.6 \%$ & $1.4 \%$ \\
\hline \multicolumn{9}{|c|}{ Developing countries } \\
\hline US dollar & $68.3 \%$ & $69.4 \%$ & $70.2 \%$ & $65.2 \%$ & $61.3 \%$ & $60.2 \%$ & $61.0 \%$ & $59.7 \%$ \\
\hline $\begin{array}{l}\text { pound } \\
\text { Japanese }\end{array}$ & $3.7 \%$ & $3.5 \%$ & $3.5 \%$ & $3.5 \%$ & $4.0 \%$ & $4.9 \%$ & $4.9 \%$ & $5.8 \%$ \\
\hline $\begin{array}{l}\text { Yen } \\
\text { Swiss }\end{array}$ & $6.1 \%$ & $5.8 \%$ & $4.6 \%$ & $4.4 \%$ & $4.0 \%$ & $4.1 \%$ & $3.7 \%$ & $2.9 \%$ \\
\hline franc & $0.4 \%$ & $0.3 \%$ & $0.2 \%$ & $0.2 \%$ & $0.2 \%$ & $0.2 \%$ & $0.2 \%$ & $0.1 \%$ \\
\hline euro & $19.9 \%$ & $19.7 \%$ & $20.5 \%$ & $25.3 \%$ & $28.5 \%$ & $29.0 \%$ & $28.5 \%$ & $29.6 \%$ \\
\hline other & $1.7 \%$ & $1.3 \%$ & $1.0 \%$ & $1.3 \%$ & $2.0 \%$ & $1.6 \%$ & $1.7 \%$ & $1.9 \%$ \\
\hline
\end{tabular}


Table 4. Decomposition of Changes in Currency Shares

\begin{tabular}{|c|c|c|c|c|c|c|c|}
\hline \multicolumn{8}{|c|}{ (end-year reserves in millions of SDRs) } \\
\hline & \multicolumn{2}{|c|}{1999} & \multicolumn{2}{|c|}{2006} & \multicolumn{3}{|c|}{ change } \\
\hline & \multirow[t]{2}{*}{ reserves } & \multirow[t]{2}{*}{ shares } & \multirow[t]{2}{*}{ reserves } & \multirow[t]{2}{*}{ Shares } & \multirow[t]{2}{*}{ total } & \multicolumn{2}{|c|}{ due to: } \\
\hline & & & & & & Valuation & other \\
\hline \multicolumn{8}{|c|}{ All countries } \\
\hline total & $1,293,361$ & & $3,342,031$ & & & & \\
\hline total allocated & $1,000,900$ & & $2,213,809$ & & & & \\
\hline US dollar & 710,452 & $71.0 \%$ & $1,433,367$ & $64.7 \%$ & $-6.2 \%$ & $-2.0 \%$ & $-4.3 \%$ \\
\hline pound & 28,915 & $2.9 \%$ & 98,131 & $4.4 \%$ & $1.5 \%$ & $0.2 \%$ & $1.4 \%$ \\
\hline Japanese Yen & 63,845 & $6.4 \%$ & 70,673 & $3.2 \%$ & $-3.2 \%$ & $0.0 \%$ & $-3.2 \%$ \\
\hline Swiss franc & 2,303 & $0.2 \%$ & 3,914 & $0.2 \%$ & $-0.1 \%$ & $0.0 \%$ & $-0.1 \%$ \\
\hline euro & 179,290 & $17.9 \%$ & 571,134 & $25.8 \%$ & $7.9 \%$ & $1.2 \%$ & $6.7 \%$ \\
\hline other & 16,094 & $1.6 \%$ & 36,591 & $1.7 \%$ & $0.0 \%$ & $0.0 \%$ & $0.0 \%$ \\
\hline \multicolumn{8}{|l|}{ memo: allocated } \\
\hline as ratio to total reserves & $77.4 \%$ & & $66.2 \%$ & & & & \\
\hline \multicolumn{8}{|c|}{ Industrial countries } \\
\hline Total & 524,949 & & 922,584 & & & & \\
\hline total allocated & 521,457 & & 919,765 & & & & \\
\hline US dollar & 383,048 & $73.5 \%$ & 661,240 & $71.9 \%$ & $-1.6 \%$ & $-2.6 \%$ & $1.0 \%$ \\
\hline Pound & 11,263 & $2.2 \%$ & 23,229 & $2.5 \%$ & $0.4 \%$ & $0.2 \%$ & $0.2 \%$ \\
\hline Japanese Yen & 34,829 & $6.7 \%$ & 32,613 & $3.5 \%$ & $-3.1 \%$ & $0.0 \%$ & $-3.1 \%$ \\
\hline Swiss franc & 372 & $0.1 \%$ & 1,976 & $0.2 \%$ & $0.1 \%$ & $0.0 \%$ & $0.1 \%$ \\
\hline Euro & 83,991 & $16.1 \%$ & 188,082 & $20.4 \%$ & $4.3 \%$ & $1.3 \%$ & $3.0 \%$ \\
\hline Other & 7,955 & $1.5 \%$ & 12,626 & $1.4 \%$ & $-0.2 \%$ & $0.0 \%$ & $-0.2 \%$ \\
\hline \multicolumn{8}{|l|}{ memo: allocated } \\
\hline as ratio to total reserves & $99.3 \%$ & & $99.7 \%$ & & & & \\
\hline \multicolumn{8}{|c|}{ Developing countries } \\
\hline Total & 768,411 & & $2,419,446$ & & & & \\
\hline total allocated & 479,443 & & $1,294,043$ & & & & \\
\hline US dollar & 327,404 & $68.3 \%$ & 772,126 & $59.7 \%$ & $-8.6 \%$ & $-1.6 \%$ & $-7.1 \%$ \\
\hline Pound & 17,653 & $3.7 \%$ & 74,903 & $5.8 \%$ & $2.1 \%$ & $0.2 \%$ & $1.9 \%$ \\
\hline Japanese Yen & 29,016 & $6.1 \%$ & 38,060 & $2.9 \%$ & $-3.1 \%$ & $0.0 \%$ & $-3.1 \%$ \\
\hline Swiss franc & 1,931 & $0.4 \%$ & 1,938 & $0.1 \%$ & $-0.3 \%$ & $0.0 \%$ & $-0.3 \%$ \\
\hline Euro & 95,299 & $19.9 \%$ & 383,052 & $29.6 \%$ & $9.7 \%$ & $1.0 \%$ & $8.7 \%$ \\
\hline Other & 8,140 & $1.7 \%$ & 23,964 & $1.9 \%$ & $0.2 \%$ & $0.0 \%$ & $0.2 \%$ \\
\hline \multicolumn{8}{|l|}{ memo: allocated } \\
\hline as ratio to total reserves & $62.4 \%$ & & $53.5 \%$ & & & & \\
\hline
\end{tabular}

Source: IMF COFER data base, International Financial Statistics, and author's calculations. Reserves converted to SDRs at end-year exchange rates. 

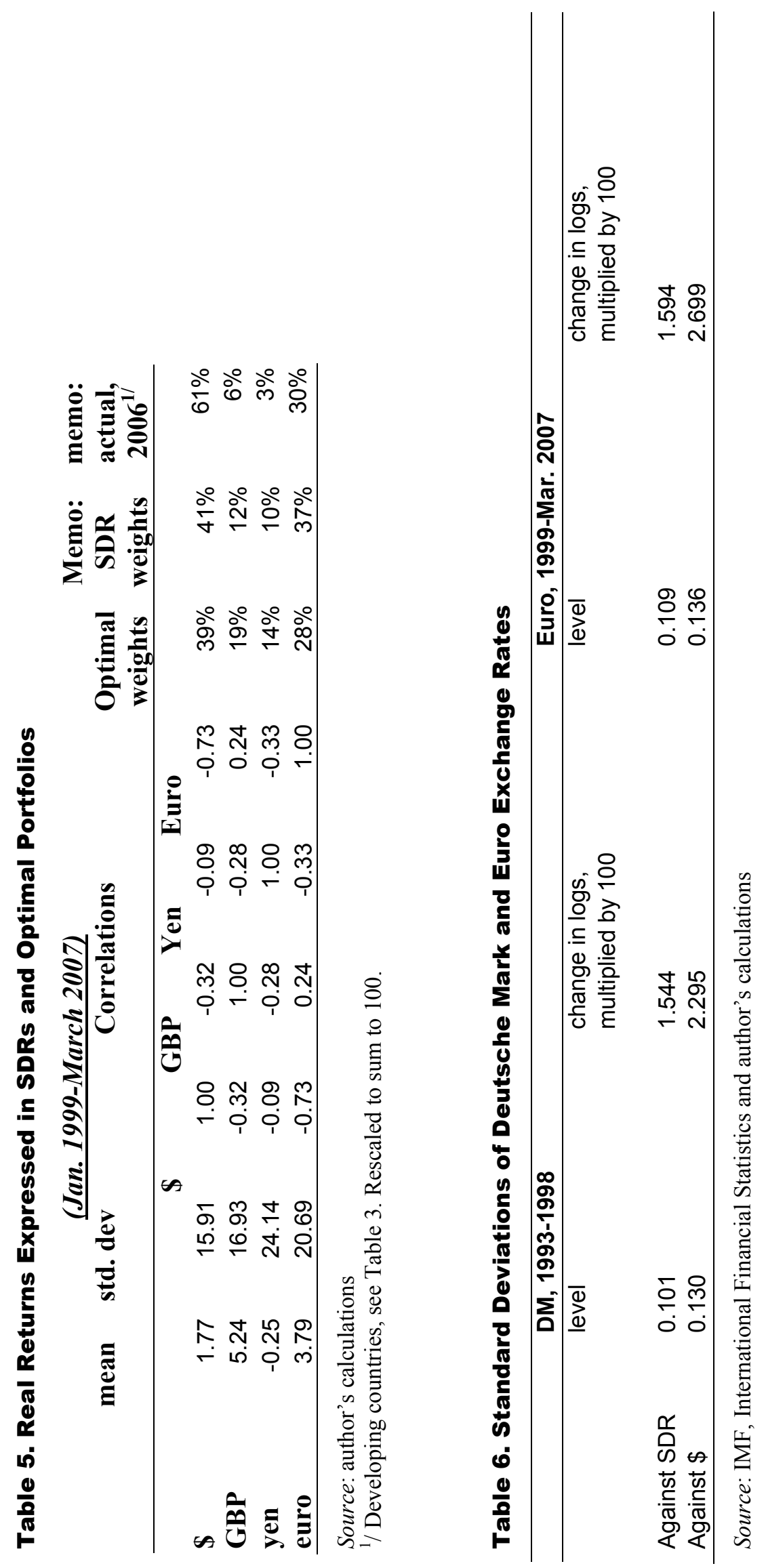